\section{Influence of Mealiness on the Firmness of Apples after Harvest}

\author{
Hiroshi Iwanami, Shigeki Moriya, Nobuhiro Kotoda, Sae Takahashi, \\ and Kazuyuki Abe \\ Department of Apple Research, National Institute of Fruit Tree Science, \\ Morioka 020-0123, Japan
}

Additional index words. Malus $\times$ domestica, breeding, softening, mealy, air space

\begin{abstract}
Changes in flesh firmness and mealiness during storage were investigated in 24 apple [Malus $\times$ sylvestris (L.) Mill. var. domestica (Borkh.) Mansf.] cultivars and selections (genotypes) up to 40 days after harvest under $20 \pm 2{ }^{\circ} \mathrm{C}$ and $85 \% \pm 5 \%$ relative humidity storage conditions. Flesh firmness was measured using a penetrometer, while mealiness was quantified by measuring the degree of cell separation in tissue induced by shaking discs of tissue in a sucrose solution. According to the relationship between the change in firmness and mealiness, the genotypes can be divided into four groups: those that did not soften and remained hard and nonmealy during storage; those that softened without mealiness; those that softened with slight mealiness; and those that softened with mealiness. Firmness decreased below $30 \mathrm{~N}$ in fruit that softened with mealiness, and the minimum firmness during storage was correlated with the degree of mealiness at 30 days of storage. The rate of softening was the highest in fruit that softened with mealiness. Therefore, it was concluded that, by measuring the firmness and changes in firmness that take place during storage, the genotypes resulting in softening with mealiness and those that result in softening without mealiness could be identified.
\end{abstract}

Consumers are much more sensitive to subtle differences in texture than in taste and tend to use texture as the primary limiting factor for acceptability (Shewfelt, 1999). Crispness and juiciness were found to be positively associated with consumer preference (AllanWojtas, 2003; Daillant-Spinnler et al., 1996) in apple [Malus $\times$ sylvestris (L.) Mill. var. domestica (Borkh.) Mansf.]. On the contrary, mealiness was found to be negative attribute (Jaeger et al., 1998), which is associated with a soft and dry texture and sharp increase in mealiness was observed during cold storage in some cultivars (Watada et al., 1980).

The differences between a mealy and a nonmealy texture can be described at the cellular level. When mechanical forces are applied to an apple, a structural failure is caused by the cells in nonmealy flesh, however, in mealy flesh, failure occurs between cells (Lapsley et al., 1992). To measure the degree of failure between cells, a tensile test is widely used (Glenn and Poovaiah, 1990; Harker and Hallett, 1992; Stow, 1989; Tu et al., 2000). Higher tensile strength indicates strong connections between cells, and lower strength indicates weak cell connections. Thus, the tensile strength is regarded as an indicator of the appearance of a mealy texture (Tu et al., 2000). However, the tensile test requires time for cutting and shaping the tissue samples. In addition, the tissue can be damaged as the samples are prepared (Harker et al., 2002). On the other hand, many researchers have tried to estimate mealiness by instrumental measurements and concluded that at least two or three measurements were necessary to estimate mealy texture (Abbott et al., 1984; Andani et al., 1999; Barreiro et al., 1998; Mehinagic et al., 2004). Therefore,

Received for publication 16 May 2005. Accepted for publication 2 Sept. 2005. this study. decreased since the 1980s; the production of strains of 'Delicious' apples was $<1 \%$ of the total apple production in 2001. One of the main reasons for the decrease in the production was that fruit of these cultivars became mealy after harvest under the cultural, climatic, and storage conditions in Japan. As a result, Japanese consumers became very sensitive to the mealy texture of apples, which made a nonmealy texture essential for new apple varieties. In Europe, it has been estimated that up to $30 \%$ of apples from northern Europe may be affected by mealiness, and the findings from cross-cultural comparisons of the perception of mealiness and consumer preference for texture attributes have been investigated (Andani et al., 2001; De Smedt, 2000; Jaeger et al., 1998). However, a limited number of cultivars have been examined and it is still unknown whether there are large variations among apple genotypes regarding the degrees of mealiness during storage.

Recently, Motomura et al. (2000) proposed a quantitative method for the measurement of mealiness, in which the degree of cell separation was assessed by shaking tissue discs in a sucrose solution. Mealiness was determined by the difference between the weights of the discs before and after shaking, and it was highly and significantly correlated $(r=0.86)$ with the degree of mealiness evaluated by sensory analysis in fruit stored at $20^{\circ} \mathrm{C}$ for 4 or 8 weeks. Nara et al. (2001) confirmed that cells separated from the shaken discs in this method were not ruptured and remained mostly intact. The advantages of this method are that many samples can be handled at one cycle of measurement and that the air space in the flesh tissue can be measured in the same cycle of measurement. The relationship between the air space in the flesh tissue and fruit softening has been observed and discussed in many studies (Harker and Ferguson, 1988; Harker

Table 1. Twenty-four apple cultivars and selections and rootstock, tree age, and harvest date evaluated in

\begin{tabular}{|c|c|c|c|c|c|c|}
\hline \multirow[b]{2}{*}{ Genotype } & \multirow{2}{*}{$\begin{array}{c}\text { Abbreviation } \\
\text { in Figure }\end{array}$} & \multirow[b]{2}{*}{ Rootstock } & \multirow{2}{*}{$\begin{array}{l}\text { Tree } \\
\text { age }^{z}\end{array}$} & \multicolumn{3}{|c|}{ Harvest date } \\
\hline & & & & $1 \mathrm{st}$ & 2nd & $3 \mathrm{rd}$ \\
\hline American Summer Pearmain & ASP & M.9 & 10 & 19 Aug. & 26 Aug. & 2 Sept. \\
\hline Sansa & SNS & M.26 EMLA & 18 & 2 Sept. & 9 Sept. & 15Sept. \\
\hline Akane & AKN & Jonathan/Marubakaido & (6) & 9 Sept. & 15 Sept. & 24 Sept. \\
\hline Tsugaru & TGR & JM7 & 8 & 9 Sept. & 15 Sept. & 24 Sept. \\
\hline McIntosh & $\mathrm{MC}$ & Marubakaido & 44 & 9 Sept. & 15 Sept. & 24 Sept. \\
\hline Silken & SLK & M.9 & 14 & 15 Sept. & 24 Sept. & 30Sept. \\
\hline Santaro & STR & Morioka \#9 & 14 & & 30 Sept. & \\
\hline Hatsuaki & HTA & Jonathan/Marubakaido & (6) & 24 Sept. & 30 Sept. & 8 Oct. \\
\hline Redgold & RG & M.9 & 10 & 30 Sept. & 8 Oct. & 14 Oct. \\
\hline Akagi & $\mathrm{AKG}$ & M.26 EMLA & Unknown & & 8 Oct. & \\
\hline Senshu & SSU & JM7 & 11 & & 8 Oct. & \\
\hline Morioka 57 & M57 & M.26 EMLA & Unknown & & 8 Oct. & \\
\hline Kitaro & KIT & M.9 EMLA & 14 & 8 Oct. & 14 Oct. & 21 Oct. \\
\hline Jonathan & JT & Marubakaido & 46 & 8 Oct. & 14 Oct. & 21 Oct. \\
\hline Starking Delicious & SD & MM.106 & 32 & & 14 Oct. & \\
\hline Jonagold & JG & JM7 & 8 & 14 Oct. & 21 Oct. & 28 Oct. \\
\hline Shinsekai & SSK & M.26 EMLA & Unknown & & 21 Oct. & \\
\hline Golden Delicious & GD & M.9 & 10 & & 21 Oct. & \\
\hline Megumi & MG & Unknown & Unknown & & 21 Oct. & \\
\hline Kotaro & KOT & JM2 & 14 & 21 Oct. & 28 Oct. & 4 Nov. \\
\hline Shinano Gold & SG & Unknown & Unknown & & 28 Oct. & \\
\hline Orin & OR & M.9 & 10 & 28 Oct. & 4 Nov. & 11 Nov. \\
\hline Fuji & FJ & JM1 & 23 & 4 Nov. & 11 Nov. & 18 Nov. \\
\hline Ralls Janet & RJ & M.9 & 10 & 11 Nov. & 19 Nov. & 26 Nov. \\
\hline
\end{tabular}

${ }^{2}$ Numeral in parenthesis indicates years since top-grafting on intermediate stock. 
and Hallett, 1992; Hatfield and Knee, 1988; Saftner et al., 1998; Vincent, 1989; Volz et al., 2003, 2004).

Mealiness developed faster in fruit of 'Delicious' stored at high temperature $\left(15^{\circ} \mathrm{C}\right)$ than at low temperature $\left(0^{\circ} \mathrm{C}\right)$ (Fisher, 1943). In a European project on mealiness of fruit, apple fruit were stored and examined under $20{ }^{\circ} \mathrm{C}$ and high relative humidity $(>90 \%)$ conditions to create several levels of mealiness, by which fruit were successfully classified into three groups: nonmealy, midpoint and mealy (De Smedt, 2000). Then, the objectives of this study were to 1) measure the degrees of mealiness in fruit of cultivars by shaking tissue discs in a solution and 2) reveal the relationship between the degrees of mealiness and changes in fruit firmness under high temperature $\left(20^{\circ} \mathrm{C}\right)$ storage conditions.

\section{Materials and Methods}

Fruitmaterials. Twenty-four apple cultivars and selections (genotypes) from the orchard at the Department of Apple Research, National Institute of Fruit Tree Science (NIFTS) in Japan were selected on the basis of the diversity of the harvest date (Table 1). The genotypes were used as parents in the NIFTS apple-breeding programs. The genotypes consist of 15 cultivars and selections that originated in Japan and nine cultivars that originated in North America. Depending on the number of fruit on a tree, one to three trees for each genotype were used, and 25 to 40 fruit samples were randomly harvested from the trees at three times weekly during the maturity period in 2004. The harvests were, however, conducted at one time in nine cultivars of the 24 genotypes because of experimental circumstances. Fruit of similar size (within $15 \%$ of average fruit weight) was picked from each genotype.

Measurement of flesh firmness, air space, and mealiness. Flesh firmness was measured using a penetrometer(FT327; McCormick Fruit Technology, Wash.) mounted on a drill press and fitted with an 11.1-mm probe on the pared surfaces of the sunny and shady sides of each fruit. The air space in the flesh tissue and mealiness were measured as described in Motomura et al. (2000) with some modifications. In brief, 10 discs ( $10 \mathrm{~mm}$ in diameter, $5 \mathrm{~mm}$ thick) were taken from just below the skin of the equatorial region of each fruit with a cork borer and immediately weighed. The discs were infiltrated in a $12 \%$ sucrose solution for 45 min under a vacuum at $11 \mathrm{kPa}$ generated by a water aspirator (A-3S; EYELA, Tokyo) and reweighed. The volume of the air space was calculated by $\mathrm{d}=$ $(\mathrm{Wi}-\mathrm{Wo}) / \mathrm{Va}$, where $\mathrm{d}=$ density of the solution, Wo and $\mathrm{Wi}=$ weight of discs before and after infiltration, respectively, and $\mathrm{Va}=$ volume of the air space expressed as $\mathrm{mL} \cdot \mathrm{g}^{-1}$ (Yamaki and Ino, 1992). The discs were then transferred to a test tube (diameter $30 \mathrm{~mm}$ ) containing $10 \mathrm{~mL}$ of the sucrose solution and shaken for $8 \mathrm{~h}\left(20^{\circ} \mathrm{C}, 180\right.$ rpm, 3-cm-wide shake; PLUS SHAKER EP-1, TAITEC, Tokyo). The degree of mealiness was calculated as $(\mathrm{Wi}-\mathrm{Ws}) / \mathrm{Wi} \times 100(\%)$, where $\mathrm{Wi}$ and Ws $=$ weight of discs before and after shaking, respectively.

Storage conditions. Three to five fruit from each harvested sample were used for the measurement at harvest and until $40 \mathrm{~d}$ after harvest at 5 or 10 dintervals. The remaining pieces were stored in 25-L containers arranged on racks in a chamber controlled at $20 \pm 2{ }^{\circ} \mathrm{C}$ and $85 \% \pm 5 \%$ relative humidity $(\mathrm{RH})$. Fruit with decay were immediately removed from the containers during storage, reducing overall fruit numbers and therefore measurement could not be continued until $40 \mathrm{~d}$ after harvest in some genotypes.

\section{Results}

Changes in firmness and degree of mealiness in the flesh during storage varied among genotypes (Fig. 1). The changes showed the same trend among fruit harvested three times during the maturity periods. Harvest data from each genotype that are representative of the trends are shown in Fig. 1. According to the relationship between change in firmness and mealiness, the genotypes can be divided into four groups: fruit that softened with mealiness, which occurred after 5 d of storage and continued to develop throughout storage (Fig. 1A); fruit that softened with slight mealiness, which occurred after $5 \mathrm{~d}$ of storage and did not develop during storage (Fig. 1B); fruit that softened without mealiness (Fig. 1C); and fruit that did not soften and remained hard and nonmealy during storage (Fig. 1D).

Firmness in most genotypes decreased rapidly after harvest, and the rapid reduction stopped within $20 \mathrm{~d}$ of storage (Fig. 1A-C). Few changes in firmness were observed after $20 \mathrm{~d}$ of storage in the genotypes.

The volume of the air space increased in tissue just below the skin of the fruit in all genotypes during storage (Fig. 2). The increases in the volume of the air space were very slow in the genotypes in which the firmness of flesh did not decrease significantly during storage (Fig.
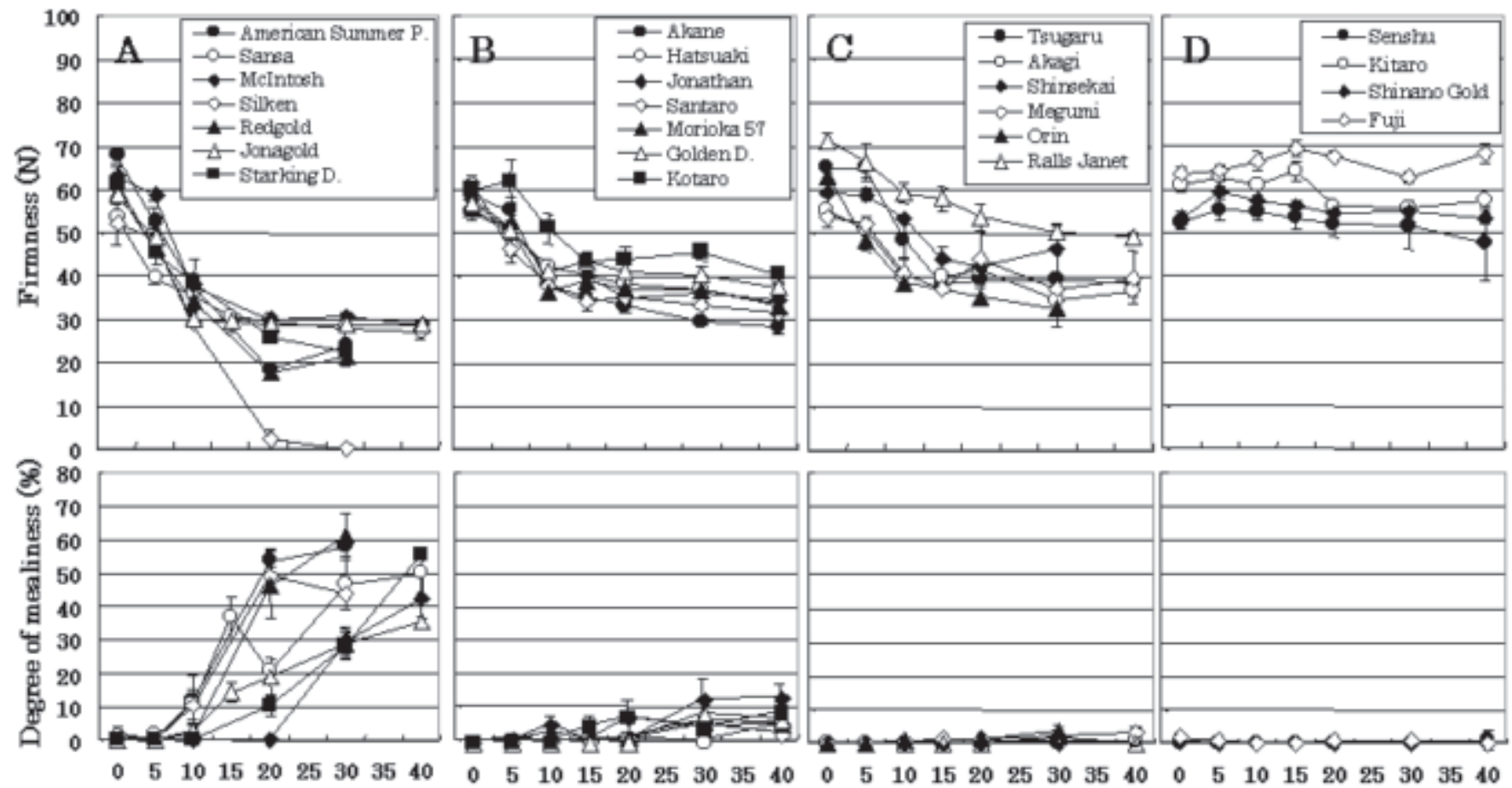

Storage duration (day)

Fig. 1. Changes in flesh firmness and degree of mealiness in 24 apple cultivars and selections during $20 \pm 2{ }^{\circ} \mathrm{C}, 85 \% \pm 5 \%$ RH storage. (A) Firmness decreased, and mealiness developed during storage; (B) firmness decreased, and some mealiness occurred but did not continue to develop; (C) firmness decreased, and mealiness did not occur; (D) firmness did not change significantly, and mealiness did not occur. Vertical bars represent SE of three to five fruit replications. 


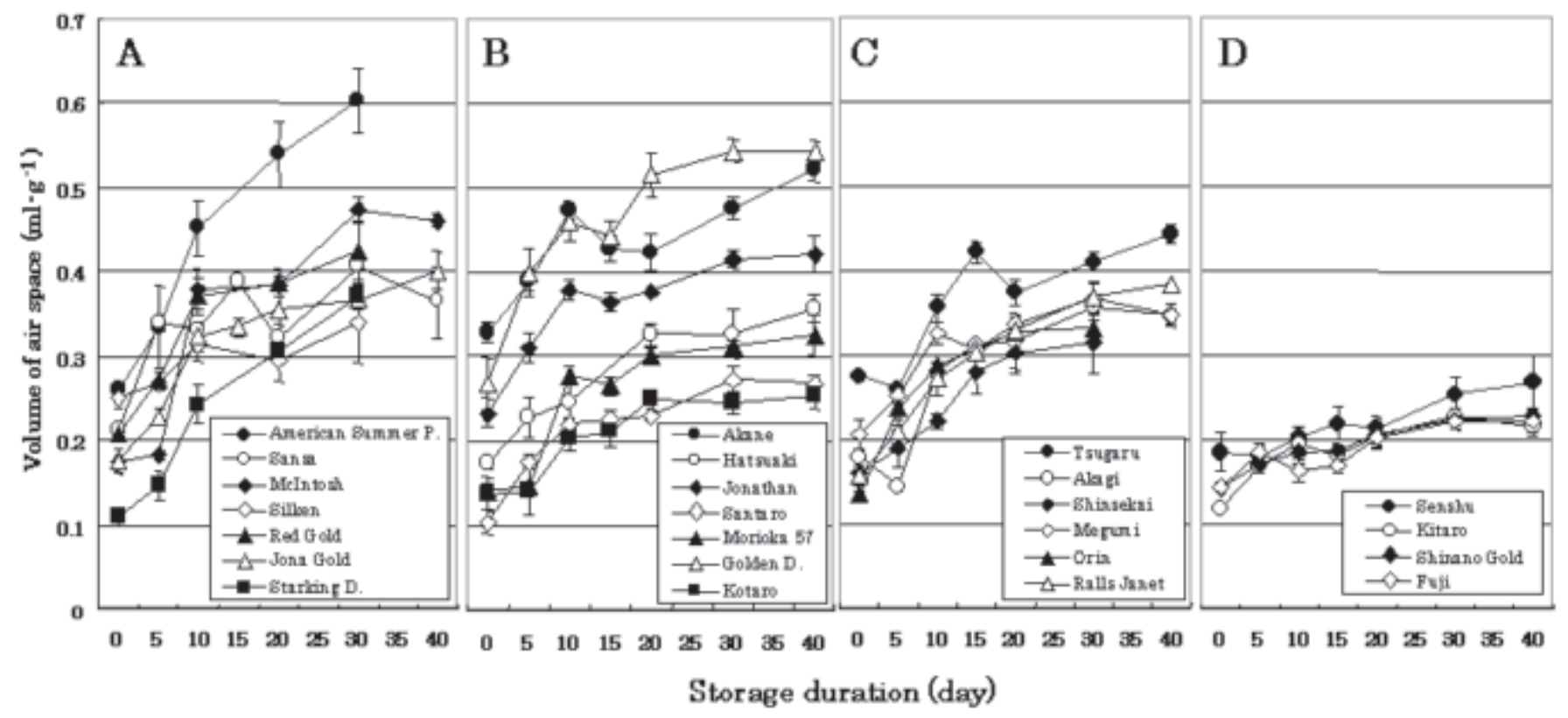

Fig. 2. Changes in volume of air space in flesh tissue in 24 apple cultivars and selections during $20 \pm 2{ }^{\circ} \mathrm{C}, 85 \% \pm 5 \%$ RH storage. (A) Firmness decreased, and mealiness developed during storage; (B) firmness decreased, and some mealiness occurred but did not continue to develop; (C) firmness decreased, and mealiness did not occur; (D) firmness did not change significantly, and mealiness did not occur. Vertical bars represent SE of three to five fruit replications.

2D). In the other genotypes, the increases were relatively fast until $10 \mathrm{~d}$ of storage and gradually became slow (Fig. 2A-C). The volume of the air space at $40 \mathrm{~d}$ of storage was around 0.4 $\mathrm{mL} \cdot \mathrm{g}^{-1}$ in almost all genotypes, including those in which the fruit softened with mealiness (Fig. 2A) and those in which the fruit softened without mealiness (Fig. 2C).

The minimum firmness of flesh during storage was significantly correlated with the degree of mealiness at $30 \mathrm{~d}$ of storage $\left(r^{2}=0.561\right)$ (Fig. $3 \mathrm{~A})$. The correlation coefficient was calculated using data of the genotypes in which the fruit softened during storage and including the data obtained at three harvest dates. This result indicated that the larger the degree of mealiness, the larger the decrease in firmness.

Genotypic differences in softening can be evaluated by comparing the softening rate, which is obtained by applying a linear regression, with a $20 \%$ reduction in firmness from the harvest date, as described by Iwanami et al. (2004). In this study, we examined the relationship between the softening rate and the occurrence or the degree of mealiness. The result was that the softening rates varied almost from 0 to $2 \mathrm{~N} \cdot \mathrm{d}^{-1}$ in genotypes in which the fruit did not show mealiness (Fig. 3B). In genotypes in which the fruit softened with just slight mealiness, the softening rates varied almost from 1 to $3 \mathrm{~N} \cdot \mathrm{d}^{-1}$, and the average of the softening rates was slightly higher than that of the softening rates in the genotypes in which the fruit softened without mealiness. On the other hand, in the genotypes in which the fruit softened with mealiness, the softening rates were around 2.8 $\mathrm{N} \cdot \mathrm{d}^{-1}$ and not very different from each other, although the degrees of mealiness at $30 \mathrm{~d}$ of storage in the genotypes differed widely from $10 \%$ to $60 \%$. This indicated that the softening rate of $2.8 \mathrm{~N} \cdot \mathrm{d}^{-1}$ was almost the upper limit under the storage conditions used in this study.

Since the volume of the air space increased during storage, we also applied the linear regression to the change in the volume of the air space from the harvest date until the date that firmness decreased by $20 \%$; this was done in the same way as for the calculation of the softening rate. The regression coefficient can be defined as the
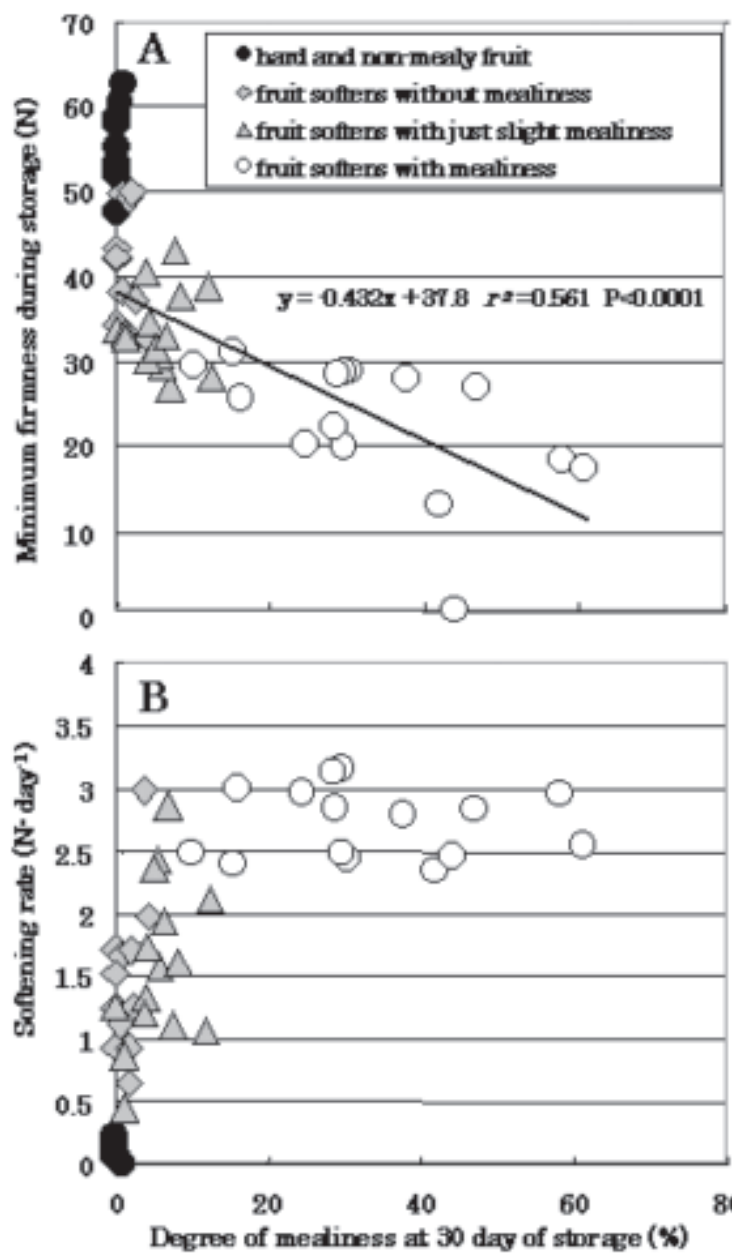

rate of increase in the air space $\left(\mathrm{mL} \cdot \mathrm{g}^{-1} \cdot \mathrm{d}^{-1}\right)$. The softening rates were closely correlated with the rates of increase in the air space in the genotypes in which mealiness did not occur or in which only slight mealiness occurred (Fig. 4). However, the rate of increase in the air space varied widely in the genotypes in which mealiness developed during storage, although the softening rates of all of them reached the upper limit.

\section{Discussion}

Instrumental firmness (penetrometer measurement) is a good predictor of the textural characteristics of crispness, hardness, and juiciness (Harker et al., 2002; Konopacka et al., 2003). Thus, the puncture test (penetrometer or firmness tester) is the most widely used test in quality standards (Harker et al., 1997). Since mealiness is the opposite of hardness and juiciness, a low measurement of

Fig. 3. Relationship between the degree of mealiness at $30 \mathrm{~d}$ of storage and (A): minimum firmness during 40 $\mathrm{d}$ of storage, $(\mathbf{B})$ : the softening rate during storage. All harvest samples described in Table 1 are included, except for those in which fruit displayed rot during storage and left insufficient amounts to continue the experiment for $30 \mathrm{~d}$ of storage. Each sample was categorized by genotype and divided into four groups, as shown in Fig. 1. The solid line represents the regression equation calculated using all data except the data of hard and nonmealy fruit. 


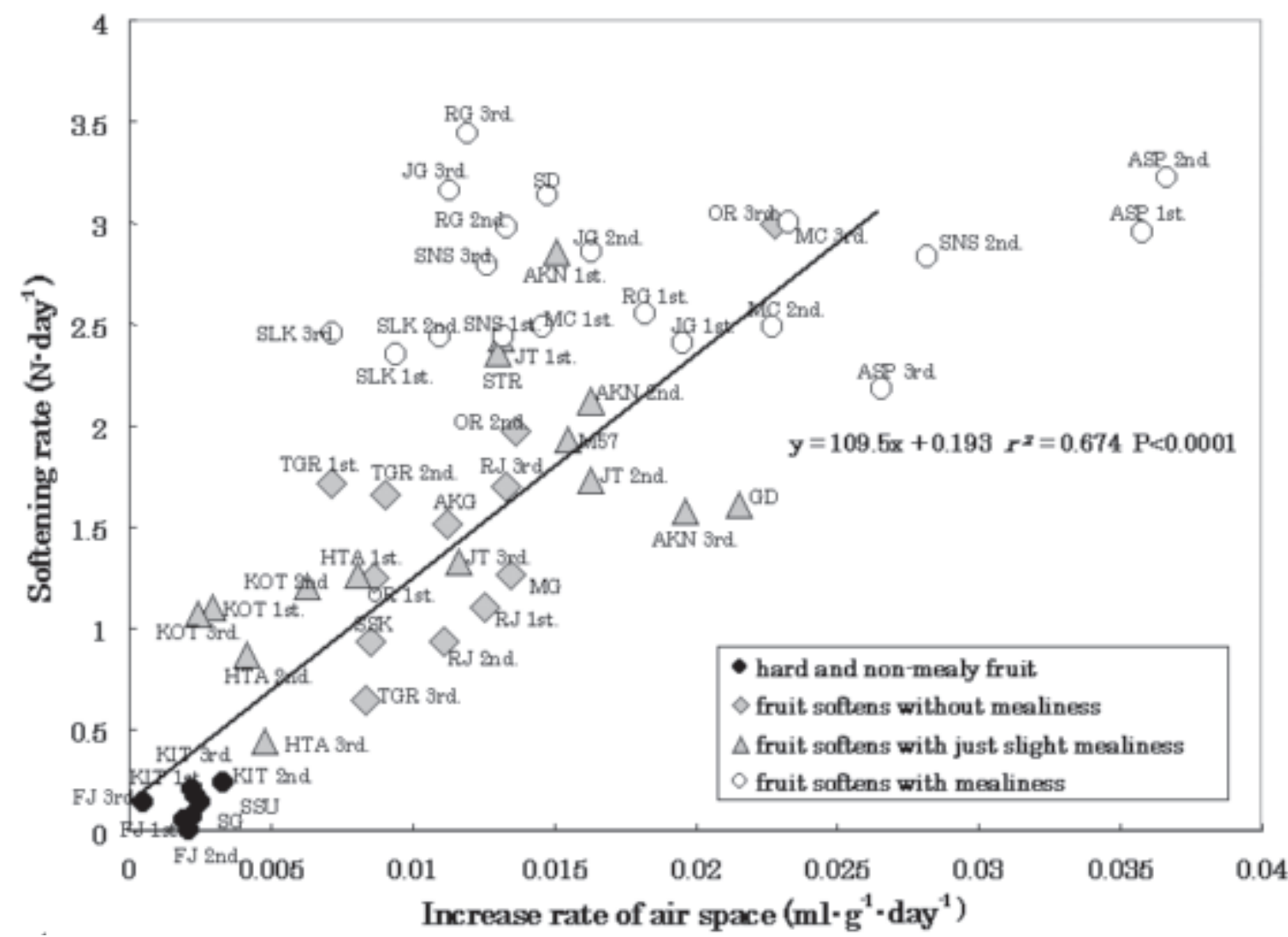

(Fig. 3B). The softening rates in fruit that softened with mealiness, however, did not correlate with the degrees of mealiness and were almost the same (around $2.8 \mathrm{~N} \cdot \mathrm{d}^{-1}$ ), although the degrees of mealiness at $30 \mathrm{~d}$ of storage widely varied from $10 \%$ to $60 \%$. This observation suggests that the softening rate is determined by the occurrence of mealiness, which was at least over $15 \%$ at $30 \mathrm{~d}$ of storage, rather than by the degree of mealiness. Therefore, comparing the softening rate could be useful for evaluating genotypic differences in storage ability because the mealy genotypes were all judged to have the highest softening rate.

A decrease in fruit firmness and a simultaneous increase in air

Fig. 4. Relationship between the rate of increase of the air space in flesh tissue and the softening rate during storage. Data include all harvest samples described in Table 1. The letters on each symbol are an abbreviation for the genotype and harvest time. Each fruit sample was categorized by genotype and divided into four groups, as shown in Fig. 1. The solid line represents the regression equation calculated using all data except the data of fruit softening with mealiness.

firmness may reflect mealiness. However, to the best of our knowledge, no study has ever elucidated whether a measurement of firmness can discriminate between genotype-dependent mealy and nonmealy fruit and whether changes in firmness can predict the onset of mealiness during storage. So far, qualitative differences in physiology or microstructure between mealy and nonmealy fruit have been well documented (Harker and Hallett, 1992; Lapsley et al., 1992), but quantitative differences or genotypic differences in the development of mealiness during storage have not been determined. Some studies have measured tensile strength constantly during storage (Johnston et al., 2001, 2002; Tu et al., 2000). However, measurements of the tensile strength indicate the combined forces that are required to fracture, rupture, and separate cells (Harker et al., 1997), and these forces continuously change during storage. The ratio of the cells that fracture, rupture, and separate also depends on the tissue conditions (Harker et al., 2002). Thus, it is not certain that a measurement of the tensile strength will show the onset of mealiness.

The method used in our study can detect only the contribution of cell separation to tissue failure and indicated that mealiness, which is defined as a structure failure caused by cell separation, occurred when firmness decreased to $40 \mathrm{~N}$ or after $10 \mathrm{~d}$ of storage in the genotypes in which the fruit softened with mealiness (Fig. 1A). These observations were consistent with those made by Harker et al. (2002), which indi- cated that cell-to-cell debonding was the primary mode of tissue failure in apples softer than 39 $\mathrm{N}$ and that there was an abrupt increase in the percentage of apples determined to be mealy when the puncture force was below $50 \mathrm{~N}$.

Our study also revealed that minimum firmness during storage depended on the degree of mealiness in fruit that softens after harvest (Fig. $3 \mathrm{~A})$. The result also showed that the minimum firmness in nonmealy fruit was never below $30 \mathrm{~N}$ during storage at $20^{\circ} \mathrm{C}$. Therefore it is probable that, when firmness is below $30 \mathrm{~N}$ during storage at $20^{\circ} \mathrm{C}$, the texture of the fruit will be mealy. In other words, occurrence of mealiness could be detected by only firmness measurement.

Mealiness does not appear for all fruit at the same time and nondestructive techniques for assessment of mealiness have been developed to classify fruit individually as suitable or unsuitable for market according to their mealiness rate (Arana, et al., 2004). Several parameters that highly correlated with mealiness have been derived from nondestructive techniques (Arana, et al., 2004; Barreiro, et al., 1999; Mehinagic, et al., 2004). However, the measurement of firmness, which is destructive, could be still useful in breeding situations because genotypes can be classified as mealy ones or nonmealy ones by measuring firmness at only one time at 30 or $40 \mathrm{~d}$ after harvest with a few fruit stored at $20^{\circ} \mathrm{C}$

The softening rate was higher in fruit that softened with mealiness than in the other fruit

space were observed during storage in apple (Harker and Hallett, 1992; Mohr, 1979; Tu et al., 2000). On the other hand, ultrastructural studies showed that cell separation resulting from degradation of the cell wall and middle lamella was taking place during storage (Glenn and Poovaiah, 1990; Lapsley et al., 1992; Mohr, 1979). Therefore, the increase in the air space is likely related to the degradation of cell wall components during storage (Harker and Hallett, 1992; Mohr, 1979). Since mealiness is assumed to result from cell separation after degradation of the middle lamella, a large air space is suggested to be symptomatic ofmealiness (Harkerand Hallett, 1992). However, in our studies, the volumes of the air space at $40 \mathrm{~d}$ of storage in the mealy genotypes were not always larger than those in the genotypes in which the fruit softened without mealiness (Fig. 2A-C). Moreover, the rates of increase in the air space in fruit that softened with mealiness varied relatively widely and were notalways larger than those in fruit that softened without or with just slight mealiness (Fig. 4). These results indicated that the increase in the air space in flesh tissue did not result from the development of cell separation. Tu et al. (2000) reported that higher relative humidity $(\mathrm{RH})$ tended to promote the development of mealy texture more than lower $\mathrm{RH}$ at $20^{\circ} \mathrm{C}$, while lower $\mathrm{RH}$ tended to increase the internal air space more than higher RH. Harker and Hallett (1992) also indicated that the development in internal air space during storage was smaller in the fruit that changed from nonmealy at harvest to mealy after storage than in the fruit that did not change to mealy. Our study showed that cell separation was rare, even in mealy genotypes, until $10 \mathrm{~d}$ of storage, although a fast increase in the air space was observed until $10 \mathrm{~d}$ of storage. Therefore, the rate of increase in the air space 
appears to represent the degree of degradation of the cell wall rather than the cell separation induced by the degradation of the middle lamella. In fact, the rate of increase in the air space was highly correlated with the softening rate in fruit in which no cell separation or just a slight amount of cell separation occurred (Fig. 4). Since tissue failure is predominantly caused by cell rupture in nonmealy fruit (Harker and Hallett, 1992), the rate of increase in the air space also seems to indicate the easiness with which cells rupture rather than the easiness with which cells separate. Therefore, the decrease in the firmness of mealy fruit in which the softening rate was at the upper limit in spite of the low increase rate of the air space may be evidence of softening induced by cell separation. Moreover, cell separation may occur even in fruit in which cell rupture occurred because mealy fruit in some genotypes showed a high rate of increase in the air space.

In conclusion, flesh firmness never decreased below $30 \mathrm{~N}$ during storage at $20{ }^{\circ} \mathrm{C}$ in fruit that softened without mealiness. On the other hand, firmness decreased below 30 $\mathrm{N}$ in fruit that softened with mealiness. The minimum firmness during storage in fruit that softened with mealiness was correlated with the degree of mealiness at $30 \mathrm{~d}$ of storage. The softening rate was the highest (around $\left.2.8 \mathrm{~N} \cdot \mathrm{d}^{-1}\right)$ in fruit that softened with mealiness under storage conditions of $20 \pm 2{ }^{\circ} \mathrm{C}$ and $85 \%$ $\pm 5 \% \mathrm{RH}$. These results suggest that the measurement of firmness and changes in firmness under shelf life conditions could be useful to discriminate genotypes that soften with mealiness from those that soften without mealiness. Furthermore, a large air space in flesh tissue, which has been suggested to be symptomatic of mealiness (Harker and Hallett, 1992), was not always observed during storage in mealy fruit. It is likely that changes in the air space during storage are related to softening without rather than with mealiness.

\section{Literature Cited}

Abbott, J.A., A.E. Watada, and D.R. Massie. 1984. Sensory and instrument measurement of apple texture. J. Amer. Soc. Hort. Sci. 109:221-228.

Allan-Wojtas, P., K.A. Sanford, K.B. McRae, and S. Carbyn. 2003. An integrated microstructural and sensory approach to describe apple texture. J. Amer. Soc. Hort. Sci. 128:381-390.

Andani, Z., V. De Smedt, and B. Nicolai. 1999. Development of mealiness in apples under shelf-life conditions. Food Sci. Technol. Today 13:203-204.

Andani, Z., S.R. Jaeger, I. Wakeling, and H.J.H. Macfie. 2001. Mealiness in apples: Towards a multilingual consumer vocabulary. J. Food Sci. 66:872-879.

Arana, I., C. Jaren, and S. Arazuri. 2004. Apple mealiness detection by nondestructive mechanical impact. J. Food Eng. 62:399-408.

Barreiro, P., C. Ortiz, M. Ruiz-Altisent, V. De Smedt, S. Schotte, Z. Andani, I. Wakeling, and P.K. Beyts. 1998. Comparison between sensory and instrumental measurements for mealiness assessment in apples: A collaborative test. J. Texture Studies 29:509-525.

Barreiro, P., J. Ruiz-Cabello, M.E. Fernandez-Valle, C. Ortiz, and M. Ruiz-Altisent. 1999. Mealiness assessment in apples using MRI techniques. Magnetic Resonance Imaging 17:275-281.

Daillant-Spinnler, B., H.J.H. MacFie, P.K. Beyts, and D. Hedderley. 1996. Relationships between perceived sensory properties and major preference directions of 12 varieties of apples from southern hemisphere. Food Qual. Preference 7:113-126.

De Smedt, V. 2000. Measurement and modeling of mealiness in apples. PhD diss. Catholic Univ. Leuven.

Fisher, D.V. 1943. Mealiness and quality of Delicious apples as affected by growing conditions, maturity and storage techniques. Sci. Agr. 23:569-588.

Glenn, G.M. and B.W. Poovaiah. 1990. Caluciummediated postharvest changes in texuture and cell wall structure and composition in 'Golden Delicious' apples. J. Amer. Soc. Hort. Sci. 115:962-968.

Harker, F.R. and I.B. Ferguson. 1988. Calcium ion transport across discs of the cortical flesh of apple fruit in relation to fruit development. Physiol. Plant. 74:695-700.

Harker, F.R. and I.C. Hallett. 1992. Physiological changes associated with development of mealiness of apple fruit during storage. HortScience 27:1291-1294.

Harker, F.R., R.J. Redgwell, I.C. Hallett, S.H. Murray., and G. Carter. 1997. Texture of fresh fruit. Hort. Rev. 20:121-224.

Harker, F.R., J. Maindonald, S.H. Murray, F.A. Gunson, I.C. Hallett, and S.B. Walker. 2002. Sensory interpretation of instrumental measurements. I. texture of apple fruit. Postharvest Biol. Technol. 24:225-239.

Hatfield, S.G.S. and M. Knee. 1988. Effects of water loss on apples in storage. Intl. J. Food Sci. Technol. 23:575-583.

Iwanami, H., M. Ishiguro, N. Kotoda, S. Takahashi, and J. Soejima. 2004. Evaluation of differences in softening of apple genotypes by linear regression. HortScience 39:1185-1188.

Jaeger, S.R., Z. Andani, I.N. Wakeling, and H.J.H. Macfie. 1998. Consumer preferences for fresh and aged apples: A cross-cultural comparison. Food Qual. Preference 9:355-366.

Johnston, J.W., E.W. Hewett, N.H. Banks, F.R. Harker, and M.L.A.T.M. Hertog. 2001. Physical change in apple texture with fruit temperature: effects of cultivar and time in storage. Postharvest
Biol. Technol. 23:13-21.

Johnston, J.W., E.W. Hewett, M.L.A.T.M. Hertog, and F.R. Harker. 2002. Temperature and ethylene affect induction of rapid softening in 'Granny Smith' and 'Pacific Rose' apple cultivars. Postharvest Biol. Technol. 25:257-264.

Konopacka, D., W.J. Plocharski, and J.Zwierz. 2003. Perception of apple quality in relation to texture attributes. Acta Hort. 604:443-448.

Lapsley, K.G., F.E. Escher, and E. Hoehn. 1992. The cellular structure of selected apple varieties. Food Structure 11:339-349.

The Ministry of Agriculture, Forestry and Fisheries of Japan. 2005. Statistics. MAFF home page (in Japanese). 6 Feb. 2005 http://www.maff. go.jp/www/info/index. html.

Mehinagic, E., G. Royer, R. Symoneaux, D. Bertrand, and F. Jourjon. 2004. Prediction of the sensory quality of apples by physical measurements. Postharvest Biol. Technol. 34:257-269.

Mohr, W.P. 1979. Silver proteinate staining of neutral polysaccharides in apple cell walls: implications relative to fruit firmness. J. Food Technol. 14:521-526.

Motomura, Y., J. Takahashi, and K. Nara. 2000. Quantitative measurement of mealiness in apple flesh. Bul. Fac. Agr. Life Sci. Hirosaki Univ. 3:23-28.

Nara, K., Y. Kato, and Y. Motomura. 2001. Involvement of terminal-arabinose and -galactose pectic compounds in mealiness of apple fruit during storage. Postharvest Biol. Technol. 22:141-150.

Saftner, R., W.S. Conway, and C.E. Sams. 1998. Effect of postharvest calcium chloride treatments on tissue water relations, cell wall calcium levels and postharvest life of 'Golden Delicious' apples. J. Amer. Soc. Hort. Sci. 123:893-897.

Shewfelt, R.L. 1999. What is quality? Postharvest Biol. Technol. 15:197-200.

Stow, J. 1989. The involvement of calcium ions in maintenance of apple fruit tissue structure. J. Expt. Bot. 40:1053-1057.

Tu, K., B. Nicolai, and J. De Baerdemaeker. 2000. Effects of relative humidity on apple quality under simulated shelf temperature storage. Scientia Hort. 85:217-229.

Vincent, J.F.V. 1989. Relationship between density and stiffness of apple flesh. J. Sci. Food Agr. 47:443-462.

Volz, R.K., F.R. Harker, and S. Lang. 2003. Firmness decline in 'Gala' apple during fruit development. J. Amer. Soc. Hort. Sci. 128:797-802.

Volz, R.K., F.R. Harker, I.C. Hallet, and A. Lang. 2004. Development of texture in apple fruit-A biophysical perspective. Acta Hort. 636:473-479.

Watada, A.E., J.A. Abbott, and R.E. Hardenburg. 1980. Sensory characteristics of apple fruit. J. Amer. Soc. Hort. Sci. 105:371-375.

Yamaki, S. and M. Ino. 1992. Alteration of cellular compartmentation and membrane permeability to sugars in immature and mature apple fruit. J. Amer. Soc. Hort. Sci. 117:951-954. 